\title{
Rights-based family planning: 15 resources to guide programming
}

Jan Kumar

Karen Hardee

\section{Recommended Citation}

Kumar, Jan and Karen Hardee. 2018. "Rights-based family planning: 15 resources to guide programming," Resource guide. Washington, DC: Population Council, The Evidence Project. 
Rights-Based Family Planning:

15 Resources to Guide Programming 
The Evidence Project

Population Council

4301 Connecticut Ave. NW, Suite 280

Washington, DC 20008 USA

tel +12022379400

evidneceproject.popcouncil.org

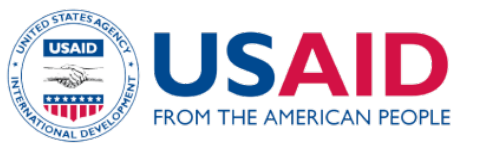

The Evidence Project is made possible by the generous support of the American people through the United States Agency for International Development (USAID) under the terms of cooperative agreement no. AID-

OAA-A-13-00087. The contents of this document are the sole responsibility of the Evidence Project and Population Council and do not necessarily reflect the views of USAID or the United States Government.

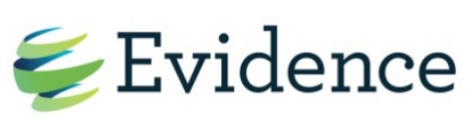

The Evidence Project uses implementation science-the strategic generation, translation, and use of evidence - to strengthen and scale up family planning and reproductive health programs to reduce unintended pregnancies worldwide. The Evidence Project is led by the Population Council in partnership with INDEPTH Network, International Planned Parenthood Federation, PATH, Population Reference Bureau, and a University Research Network.

Published in January 2018.

Suggested citation: Kumar, Jan and Karen Hardee. 2017. "Rights-Based Family Planning: 15 Resources to Guide Programming,” Resource Guide. Washington, DC: Population Council, The Evidence Project.

(C) 2018 The Population Council, Inc. 


\section{Table of Contents}

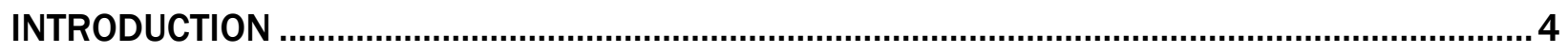

The Basis for Human Rights and Family Planning............................................................................... 4

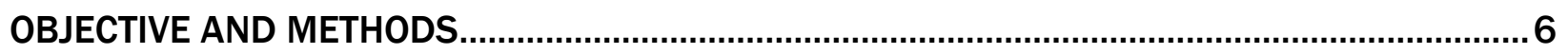

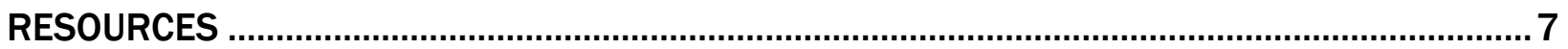

FP2020 Rights and Empowerment Principles for Family Planning ........................................................ 8

Ensuring Human Rights in the Provision of Contraceptive Information and Services ............................. 9

Ensuring Human Rights Within Contraceptive Service Delivery: Implementation Guide..........................11

Quality of Care in Contraceptive Information and Services, Based on Human Rights Standards: A

Checklist for Health Care Providers .................................................................................................. 12

Quality of Care in the Context of Rights-based Family Planning....................................................... 14

Monitoring Human Rights in Contraceptive Services and Programmes ................................................16

Defining Qualtiy in Contraceptive Counseling................................................................................... 17

How Does Quality of Care Relate to a Rights-based Approach to Family Planning................................. 18

Voluntary Family Planning Programs that Respect, Protect, and Fulfill Human Rights: A Conceptual

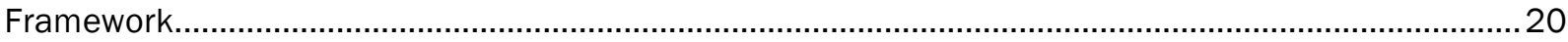

Voluntary Family Planning Programs that Respect, Protect, and Fulfill Human Rights: Conceptual

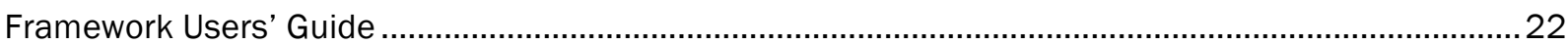

Checkpoints for Choice: An Orientation and Resource Package ...........................................................23

A Human Rights-Based Approach to Programming: Practical Implementation Manual and Training

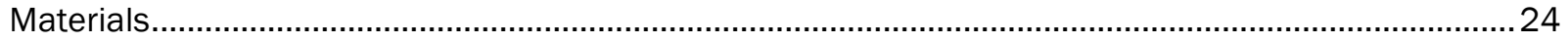

The Right to Contraceptive Information and Services for Women and Adolescents: Briefing Paper ...... 26 Voluntary Family Planning Programs that Respect, Protect, and Fulfill Human Rights: A Systematic

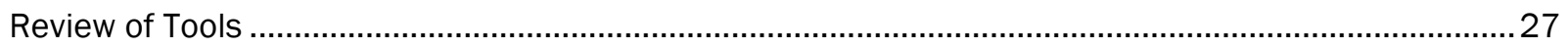

Reproductive Rights are Human Rights: A Handbook for National Human Rights Institutions ...............28

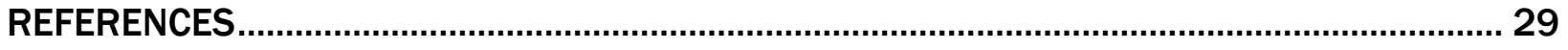




\section{Introduction}

The right to sexual and reproductive health is not only an integral part of the general right to health but fundamentally linked to the enjoyment of many other human rights, including the rights to education, work and equality, as well as the rights to life, privacy and freedom from torture, and individual autonomy, UN experts have said in an authoritative new legal commentary.

OHCHR, 2016

The ambitious FP2020 goal of providing family planning services to 120 million more women and girls that emerged from the Family Planning Summit in London in 2012 has refocused attention on the need to ensure that family planning programs respect, protect and fulfill individual's human rights and that programs are implemented using a rights-based approach. The current challenge is how to operationalize human rights in existing family planning programs and the design of new projects. A number of resources are available to help stakeholders do so: the purpose of this paper is to review 15 key resources currently available to guide family planning programming.

\section{THE BASIS FOR HUMAN RIGHTS AND FAMILY PLANNING}

The human rights dimension of family planning programs has been recognized for nearly 50 years. People's right to decide freely and responsibly the number and spacing of their children and to have access to related information was asserted by the international community at the Conference on Human Rights in Tehran in 1968. This right has been reaffirmed and embellished by various bodies in numerous declarations and conventions over the years, notably the 1979 Convention on the Elimination of all forms of Discrimination Against Women (CEDAW), the 1994 International Conference on Population and Development (ICPD), and the 1995 Fourth World Conference on Women.

Following the ICPD in 1994, several organizations, including the International Planned Parenthood Federation and the Center for Reproductive Rights, articulated the foundation for human rights in family planning programs by identifying a dozen core human rights that underlie reproductive rights ${ }^{1}$ (IPPF, 1996; Center for Reproductive Rights, 2009). Cook and Erdman (2008), human rights attorneys, grouped these rights into three categories of reproductive rights:

- Those related to reproductive self-determination;

- Those related to access to sexual and reproductive health services, commodities, information and education; and

- Those related to equality and non-discrimination.

The Right to Sexual and Reproductive Health, as articulated in General Comment No. 22 (2016) by the Committee on Economic, Social and Cultural Rights, UN Economic and Social Council, builds on Comment 14, Article 12 of the International Covenant on Economic, Social and Cultural Rights, on the right to health.

${ }^{1}$ These 12 rights are: The Right to Life; Liberty and Security of the Person; The Right to Equality, and to be Free from all Forms of Discrimination; The Right to Privacy; The Right to Freedom of Thought; The Right to Information and Education; The Right to Choose Whether or Not to Marry and to Found and Plan a Family; The Right to Decide Whether or When to Have Children; The Right to Health Care and Health Protection; The Right to the Benefits of Scientific Progress; The Right to Freedom of Assembly and Political Participation; and The Right to be Free from Torture and Ill Treatment. 
Comment 14 is a legally binding instrument that stipulates that governments are obligated to ensure that all healthcare information, services and commodities are available, accessible, acceptable and of the highest possible quality (commonly encapsulated in the acronym AAAQ). Comment 22 expands Comment 14 to articulate the right to the highest attainable standard of sexual and reproductive health (OCHCR 2016).

In addition, there are principles that guide how family planning programs should be planned and carried out in order to respect, protect and fulfill these human rights. PANEL is a commonly accepted acronym, standing for Participation, Accountability, Non-discrimination and equality, Empowerment, and Links to the treaty bodies that make commitments legally binding.

While these rights and related principles are recognized by the international community and are increasingly a part of the discourse in family planning circles, a gap persists between the rhetoric of human rights and integrating these rights into family planning programming in actual practice. There is much talk about achieving universal access to high quality contraceptive information and services, and protecting clients' right to make full, free and informed contraceptive choices from among a range of options, but governments and programs still struggle with what a rights-based approach to family planning entails and how to operationalize it. 


\section{Objective and Methods}

How to move beyond the rhetoric to put a rights-based approach into action in family planning programs has been the subject of a number of resources published over the past few years. The proliferation of resources has caused some confusion among practitioners, who may be unclear about whether or not the resources address the same human rights, how they differ in approach, and how each resource could be used to guide family planning programming.

\section{AVAILABLE RESOURCES ON PROGRAMIMING HUMAN RIGHTS AND FAMILY PLANNING}

Available resources on rights-based programming for family planning vary in purpose, structure, scope and detail. They offer different frameworks and guidance; some are more comprehensive and programmatic than others. Faced with an abundance of resource documents, family planning stakeholders need help in deciding which to use for what purpose. This calls for a summary of key resources to foster understanding of how they compare to one another.

This paper addresses this need by annotating 15 documents using a consistent format that allows for easy comparison. It provides a description of each resource based on text drawn from the documents itself. The resources include human rights elements; principles and related recommended actions; comprehensive programming frameworks; how-to operational guidance; and tools that support rights-based FP programs.

The intention of this review is to provide an overview of key, recent publications to enable potential users to make an informed determination of what to apply to best meet their needs.

\section{SELECTION CRITERIA}

This review does not cover all existing materials related to a rights-based approach to family planning. Rather, it captures key resources with global applicability published since 2010 that support rights-based family planning programming. It does not cover the full spectrum of resources that are specific to related issues, such as empowerment, community engagement, informed choice, quality of care, program monitoring, and accountability mechanisms, among others.

Table 1 shows a list of the resources included in the paper. 


\section{Resources}

TABLE 1 | List of Resources Included in the Paper

\section{RESOURCE}

1

FP2020: Rights and Empowerment Principles

for Family Planning

Ensuring Human Rights in the Provision of

Contraceptive Information and Services

3 Ensuring Human Rights Within Contraceptive

Service Delivery: Implementation Guide

Quality of Care in Contraceptive

Information and Services,

4 Based on Human Rights Standards:

A Checklist for Health Care Providers

5 Quality of Care in the Context of Rights-based

Family Planning

6 Monitoring Human Rights in Contraceptive

Services and Programmes

7 Defining Quality in Contraceptive Counseling

How Does Quality of Care Relate to a Rights-

8 Based Approach to Family Planning Programs?

Voluntary Family Planning Programs that

9 Respect, Protect, and Fulfill Human Rights: A Conceptual Framework

Voluntary Family Planning Programs That

10 Respect, Protect, and Fulfill Human Rights:

Conceptual Framework Users' Guide

11 Checkpoints for Choice: An Orientation and

Resource Package

A Human Rights-Based Approach to

12 Programming: Practical Implementation

Manual and Training Material

The Right to Contraceptive Information and

13 Services for Women and Adolescents: Briefing Paper

Voluntary Family Planning Programs that

14 Respect, Protect, and Fulfill Human Rights: A 2013

Systematic Review of Tools

Handbook for National Human Rights

15 Institutions: Reproductive Rights are Human Rights
YEAR PUBLISHER

PAGE

2014 FP2020

2014 WHO

9

2015 WHO \& UNFPA

11

2017 WHO

2017 Population Council

2017 WHO

16

2017 Harvard and UCSF

2015 Population Council

18

2013 Futures Group \& EngenderHealth

20

2014 Futures Group \& EngenderHealth

22

2014 EngenderHealth/The RESPOND

Project

UNFPA with the Harvard School of Public Health

24

Center for Reproductive Rights and UNFPA

Futures Group and

EngenderHealth

UNFPA, Danish Institute for Human Rights, the Office of the UN High Commissioner for Human 


\section{FP2020 RIGHTS AND EMPOWERMENT PRINCIPLES FOR FAMILY PLANNING}

\begin{tabular}{|c|c|c|c|}
\hline DATE & PUBLISHER & LANGUAGES & FUNDING ORGANIZATION \\
\hline 2014 & FP2020 & English $\mid$ French & FP2020 \\
\hline
\end{tabular}

\section{TYPE OF RESOURCE}

Human Rights Principles \& Program Guidance

\section{PURPOSE}

This brief is intended to establish a common understanding of rights principles as they relate to ten dimensions of family planning (FP). It can be used to heighten awareness of the essential elements of human rights that must be respected, protected and fulfilled in FP programs. It also offers broad direction regarding program design, monitoring, commodities, product and service promotion and sector engagement.

\section{INTENDED AUDIENCES/USERS}

A broad range of FP stakeholders, including donors, policymakers and program managers.

\section{SCOPE \& CONTENT}

Ten rights-related principles and FP program dimensions are defined, and for each one broad recommendations are offered for policy and programming, measurement and markets.
1. Agency and autonomy
6. Empowerment
2. Availability
7. Equity and non-discrimination
3. Accessibility
8. Informed choice
4. Acceptability
9. Transparency and accountability
5. Quality
10. Voice and participation

\section{DEVELOPMENT PROCESS}

This product was conceptualized and developed by FP2020's Rights \& Empowerment Working Group and informed by input from members of the FP2020 Country Engagement, Performance Monitoring \& Accountability, and Market Dynamics Working Groups.

\section{HOW TO USE IT / RESOURCES REQUIRED}

This brief document frames essential human rights elements in FP programs in a concise manner. It can be used as a simple checklist and broad programmatic guide at a high conceptual level. No resources are required to use this document itself; however, additional guidance is necessary to operationalize its broad recommendations.

\section{WEB LINK}

English http://ec2-54-210-230-186.compute-1.amazonaws.com/wpcontent/uploads/2014/12/FP2020_Statement_of Principles_FINAL.pdf

French http://ec2-54-210-230-186.compute-1.amazonaws.com/wpcontent/uploads/2014/12/FP2020_Statement_of_Principles_French_SinglePg_12.2.14.pdf 


\section{ENSURING HUMAN RIGHTS IN THE PROVISION OF CONTRACEPTIVE INFORMATION AND SERVICES}

\begin{tabular}{|c|c|c|c|}
\hline DATE & PUBLISHER & LANGUAGES & FUNDING ORGANIZATION \\
\hline 2014 & WHO & \begin{tabular}{l|l|l} 
English & French & Spanish
\end{tabular} & WHO \\
\hline
\end{tabular}

TYPE OF RESOURCE

Program Guidelines \& Recommendations

\section{PURPOSE}

This document is designed to provide guidance on some of the priority actions needed to ensure that different human rights dimensions are systematically and clearly integrated into the provision of contraceptive information and services. It is structured around nine human rights standards and principles, for which it offers recommendations.

\section{INTENDED AUDIENCES/USERS}

Policy makers, managers, providers and other stakeholders in the health sector.

\section{SCOPE \& CONTENT}

The guidance recommends evidence-based interventions to support nine human rights components and principles:

1. Non- discrimination

2. Availability of contraceptive information and services

3. Accessibility of contraceptive information and services

4. Acceptability of contraceptive information and services

5. Quality of contraceptive information and services

6. Informed decision-making

7. Privacy and confidentiality

8. Participation

9. Accountability

It is considered a first step for addressing human rights obligations; it does not address all necessary FP program elements comprehensively. The intention is for it to be expanded and updated over time.

\section{DEVELOPMENT PROCESS}

The authors followed the WHO standards for guideline development. They identified priority questions and outcomes, and then retrieved, assessed and synthesized evidence using the systematic GRADE approach. This proved problematic for the topic, which doesn't lend itself to randomized controlled trials. The majority of the data couldn't be entered into the GRADE system. The authors developed narrative evidence summaries to fill gaps. They then drafted recommendations, which were reviewed and revised by a Guideline Development Group based on the evidence at a consultation.

\section{HOW TO USE IT / RESOURCES REQUIRED}

Any FP stakeholder can use this resource to inform their program. No special resources are required. 
WEB LINK

English http://apps.who.int/iris/bitstream/10665/102539/1/9789241506748 eng.pdf?ua=1;

http://apps.who.int/iris/bitstream/10665/102543/1/WHO_RHR_14.02_eng.pdf?ua=1

French http://apps.who.int/iris/bitstream/10665/126317/1/9789242506747_fre.pdf?ua=1\&ua=1

Spanish http://apps.who.int/iris/bitstream/10665/126318/1/9789243506746_spa.pdf?ua=1\&ua=1 


\section{ENSURING HUMAN RIGHTS WITHIN CONTRACEPTIVE SERVICE DELIVERY: IMPLEMENTATION GUIDE}

\begin{tabular}{cccc}
\hline DATE & PUBLISHER & LANGUAGES & FUNDING ORGANIZATION \\
2015 & WHO \& UNFPA & English & WHO \& UNFPA \\
\hline
\end{tabular}

\section{TYPE OF RESOURCE}

This implementation guide is a companion to the WHO's "Ensuring Human Rights in the Provision of Contraceptive Information and Services: Guidance and Recommendations" (2014), described above. It merges the recommendations that support nine principles and standards outlined by WHO with the content of UNFPA's "Choices not Chance: UNFPA’s Family Planning Strategy 2012-2020."

\section{PURPOSE}

This document is designed to provide guidance on some of the priority actions needed to ensure that different human rights dimensions are systematically and clearly integrated into the provision of contraceptive information and services. It is structured around nine human rights standards and principles, for which it offers recommendations.

\section{INTENDED AUDIENCES/USERS}

This document is addressed to mid-level policymakers and program managers/implementers involved with family planning service provision in all settings.

\section{SCOPE \& CONTENT}

The guide "translates" the nine human rights standards laid out in the WHO guidance into corresponding programmatic concepts, or categories for program implementation. For each concept or category, it provides introductory text, the related recommendations from the WHO guidance, and key considerations to think about and illustrative actions that could be taken. It also offers country examples of implementation of the recommendations. The Guide recognizes that additional actions are likely to be required for full implementation of the $\mathrm{WHO}$ recommendations. It highlights the importance of grounding all activities in the human rights principles of participation and accountability.

\section{DEVELOPIMENT PROCESS}

This implementation guide was developed by identifying key considerations and action points for each of the WHO guidelines based on assessment and synthesis of evidence. An expert working group from UNFPA and WHO that included country-level programming experts reviewed the draft document and provided input. Human rights and gender equality principles were systematically incorporated in the development of the guide.

\section{HOW TO USE IT / RESOURCES REQUIRED}

Use of the guide does not require any special resources.

\section{WEB LINK}

http://apps.who.int/iris/bitstream/10665/158866/1/9789241549103_eng.pdf?ua $=1$ 


\section{QUALITY OF CARE IN CONTRACEPTIVE INFORIMATION AND SERVICES, BASED ON HUMAN RIGHTS STANDARDS: A CHECKLIST FOR HEALTH CARE PROVIDERS}

\begin{tabular}{|c|c|c|c|}
\hline DATE & PUBLISHER & LANGUAGES & FUNDING ORGANIZATION \\
\hline 2017 & WHO & English & $\begin{array}{c}\text { The Bill and Melinda Gates } \\
\text { Foundation }\end{array}$ \\
\hline
\end{tabular}

\section{TYPE OF RESOURCE}

This checklist for providers complements the WHO guidelines on Ensuring buman rights in the provision of contraceptive information and services: Guidance and recommendations, and the Implementation Guide published jointly with UNFPA in 2015 (see the link under resource 3 above). The checklist also builds on the WHO vision document, "Standards for Improving Quality of Care for Maternal and Newborn Care," as well as ongoing work under WHO's Quality, Equity and Dignity initiative.

\section{PURPOSE}

This checklist is intended for health care providers working at the primary health care level, who directly provide contraceptive information and services. The checklist is intended to be used along with guidance from WHO and also from partners to identify quality of care issues that need to be addressed. The guide also includes suggested steps for improvement.

\section{INTENDED AUDIENCES/USERS}

Health care providers, with support from program managers.

\section{SCOPE \& CONTENT}

The checklist includes questions for providers to answer to the best of their ability, on a 1-5 scale, to identify components of services in need of improvement. Scores under 3 suggest a need for urgent action (based on steps suggested below), whereas scores higher than 3 suggest a good level of facility preparedness to ensure quality, with some follow-up actions required.

This document covers five areas of competence health care providers need to provide quality of care in contraceptive information and services. Based on both human rights standards and available public health evidence, these are:

- Respecting users' privacy and guaranteeing confidentiality.

- Autonomous decision-making and confidentiality.

- Physical integrity and private spaces for counselling and examination.

- Choice of contraceptives.

- Ensuring accurate and unbiased information.

- Ensuring non-judgmental and respectful counselling and interactions with users.

- Ensuring a range of contraceptive methods.

- Fostering an accessible and acceptable service.

- Involvement of users in improving services.

- Fostering continuity of care and follow-up and ensuring your own efficacy.

\section{DEVELOPMENT PROCESS}

This implementation guide was developed by identifying key considerations and action points for each of the WHO guidelines, based on assessment and synthesis of evidence. An expert working group from UNFPA and WHO that 
included country-level programming experts reviewed the draft document and provided input. Human rights and gender equality principles were systematically incorporated in the development of the guide.

HOW TO USE IT / RESOURCES REQUIRED

Use of the guide does not require any special resources.

WEB LINK

http://apps.who.int/iris/bitstream/10665/254826/1/9789241512091-eng.pdf 


\section{QUALITY OF CARE IN THE CONTEXT OF RIGHTS-BASED FAMILY PLANNING}

\begin{tabular}{|c|c|c|c|}
\hline DATE & PUBLISHER & LANGUAGES & FUNDING ORGANIZATION \\
\hline 2017 & Population Council & English & $\begin{array}{c}\text { The David and Lucile Packard } \\
\text { Foundation }\end{array}$ \\
\hline
\end{tabular}

\section{TYPE OF RESOURCE}

This policy brief describes an updated version of the Bruce Quality of Care Framework for family planning to incorporate aspects of quality that are included in a rights-based approach to family planning.

\section{PURPOSE}

The purpose of this review is to compare the components of the 1990 Quality of Care (QOC) Framework for Family Planning (Bruce, 1990) with human rights frameworks in order to propose an updated QOC Framework that fits within the context of a human rights approach.

\section{INTENDED AUDIENCES/USERS}

Designers, implementers, funders and advocates of family planning programming.

\section{SCOPE \& CONTENT}

This review compares the framing of quality in: the Bruce Framework; General Comment 14 on the Right to the Highest Attainable Standard of Health and General Comment 22 on the Right to the Highest Attainable Standard of Sexual and Reproductive Health; the Voluntary Human Rights-based Family Planning Framework; and the FP2020 Rights and Empowerment Principles. Based on this analysis and comparison, an updated Qualify of Care framework is presented.

\section{Modified QOC Framework}

1. Structure (quality of services or readiness of services)

a. Choice (availability of the app appropriate number and type of methods and required equipment)

b. Availability of trained/competent provider in:

- Providing contraceptive methods safely by ensuring compliance with infection prevention practices

- Treating clients with dignity and respect

- Appropriate information exchange with clients

c. Availability of space to ensure audio and visual privacy

d. Availability of appropriate constellation of RH services

2. Service-giving process (quality of care)

a. Appropriate information exchange with clients to ensure:

- Selection of a method appropriate to client's needs and circumstances by soliciting information from them about their reproductive intentions, family circumstances, prior use of contraception, and preferred method; and by providing information on alternate methods appropriate to their needs

- Effective contraceptive use by informing clients about such items as how to use the method selected, potential side effects and how to manage them if they occur

- Continuity of care and contraceptive use by informing clients when to come back for resupply and possibility of switching the method, provider, or service outlet whenever the selected method/provider/outlet does not remain suitable

b. Interpersonal relations including:

- Treating clients with dignity and respect 
- Ensuring audio and visual privacy and confidentiality

\section{DEVELOPMENT PROCESS}

This update of the QOC Framework for family planning was undertaken by the Population Council as part of a project on quality of care funded by the David and Lucile Packard Foundation. Dr. Anrudh Jain undertook this update based on decades of work studying quality of care, review of human rights frameworks that included quality of care and discussions with experts on quality of care and rights-based family planning.

\section{HOW TO USE IT / RESOURCES REQUIRED}

Use of this review does not require any special resources.

WEB LINK

http://www.popcouncil.org/uploads/pdfs/2017RH_QoCRightsBasedFP.pdf 


\section{MONITORING HUMAN RIGHTS IN CONTRACEPTIVE SERVICES AND PROGRAMMES}

\begin{tabular}{|c|c|c|c|}
\hline DATE & PUBLISHER & LANGUAGES & FUNDING ORGANIZATION \\
\hline 2017 & WHO & English & $\begin{array}{c}\text { The Bill and Melinda Gates } \\
\text { Foundation }\end{array}$ \\
\hline
\end{tabular}

\section{TYPE OF RESOURCE}

This resource is a tool for monitoring human rights in contraceptive services and programmes.

\section{PURPOSE}

This tool builds on WHO guidelines on Ensuring buman rights in the provision of contraceptive information and services: Guidance and recommendations, and the Implementation Guide published jointly with UNFPA in 2015 (see links under resources 2 and 3 above). The tool is intended for use by countries to assist them in strengthening their human rights efforts in contraceptive programming.

\section{INTENDED AUDIENCES/USERS}

Designers and implementers, funders and advocates of family planning programming.

\section{SCOPE \& CONTENT}

This resource includes and introduction explaining the development and organization of the tool and instructions on how to use the tool. The resource also includes indicators to support monitoring of human rights in eight categories of programming:

1. Ensuring Access for All

2. Commodities, logistics and procurement

3. Organization of health-care facilities, outreach and integration

4. Quality of care

5. Comprehensive sexuality education

6. Humanitarian context

7. Participation by actual and potential users of services

8. Accountability to those using the services.

\section{DEVELOPMENT PROCESS}

This tool was initiated and coordinated by Rajat Kosla and Moazzam Ali from the Department of Reproductive Health and Research of WHO. The document was written by them and colleagues at the University of California Los Angeles (Sofia Gruskin, Shubha Kumar and Alexandra Nicholson). Input was received from an expert advisory group.

\section{HOW TO USE IT / RESOURCES REQUIRED}

Use of this review does not require any special resources.

\section{WEB LINK}

http://apps.who.int/iris/bitstream/10665/259274/1/9789241513036-eng.pdf?ua=1 


\section{DEFINING QUALTIY IN CONTRACEPTIVE COUNSELING}

\begin{tabular}{|c|c|c|c|}
\hline DATE & PUBLISHER & LANGUAGES & FUNDING ORGANIZATION \\
\hline 2017 & Contraception (Journal) & English & $\begin{array}{c}\text { The David and Lucile Packard } \\
\text { Foundation }\end{array}$ \\
\hline
\end{tabular}

\section{TYPE OF RESOURCE}

This article synthesizes concepts from family planning and the broader health and health communication fields, together with concepts from human rights guidance related to contraceptive services, to create a new quality in contraceptive counseling framework.

\section{PURPOSE}

The purpose of this framework is to bolster both measurement and service delivery improvement in contraceptive counseling.

\section{INTENDED AUDIENCES/USERS}

Designers, implementers, funders and advocates of family planning programming.

\section{SCOPE \& CONTENT}

The framework for quality in contraceptive counseling includes a process comprising needs assessment, decisionmakign support and method choice and follow up and is built on six foundational relationshiop building elements: privacy, confidentiality, non-discrimination, respect, empathy, and trust. The review also includes implications for use of the framework to serve as a foundation to move beyond a focus on contraceptive access and uptake, towards robust, routine focus on individuals' experiences communicating with contraceptive providers.

\section{DEVELOPMENT PROCESS}

The framework was developed by researchers from the Harvard T.H. Chan School of Public Health (Kelsey Holt and Ana Langer) and the Unviersity of California San Francisco (Christine Dehlendorf) through reviewing relevant literature and consulting with experts in contraceptive counseling and research, programmatic and policy experise.

\section{HOW TO USE IT / RESOURCES REQUIRED}

Use of this review does not require any special resources.

\section{WEB LINK}

http://www.contraceptionjournal.org/article/S0010-7824(17)30167-1/fulltext 


\section{HOW DOES QUALITY OF CARE RELATE TO A RIGHTS-BASED APPROACH TO FAMILY PLANNING}

\begin{tabular}{|c|c|c|c|}
\hline DATE & PUBLISHER & LANGUAGES & FUNDING ORGANIZATION \\
\hline 2017 & Population Council & English & $\begin{array}{c}\text { The David and Lucile Packard } \\
\text { Foundation }\end{array}$ \\
\hline
\end{tabular}

\section{TYPE OF RESOURCE}

This is a review and analysis of concepts, programmatic approaches and frameworks for quality of care and rightsbased family planning programming.

\section{PURPOSE}

This review compares definitions of quality and contrasts them with the essentials of a rights-based approach. Its aim is to create common understanding of what these terms mean, where they overlap and how they differ. The paper argues for adopting the broader construct of rights-based programming as a foundation for family planning programs, and that programs should maintain a focus on service quality within the broader rights approach, rather than limiting their focus to assuring and improving quality.

\section{INTENDED AUDIENCES/USERS}

Designers, implementers, funders and advocates of family planning programming.

\section{SCOPE \& CONTENT}

"This paper compares definitions of quality and contrasts them with the essentials of a rights-based approach. It aims to create common understanding of what these terms mean, where they overlap and how they differ. The comparative review revealed that quality of care is essentially a supply-side construct that relates to the conditions and actions programs should ensure for their clients during service delivery. It is rooted in evidence-based medical science and focuses on the safety and effectiveness of services. Its orientation is primarily around the health system and service provider competencies and behaviors towards those they serve.

In contrast, a rights-based approach centers on the dignity, needs, and autonomy of individual clients and potential clients. It is about empowering and engaging people to exercise self-determination for their health and fertility, and eliminating policy and program barriers and practices, including all forms of discrimination, which would block anyone from enjoying their rights. While it includes quality of care, a rights-based approach is more an ethical model than a medical one. It is a broader programmatic construct than quality of care, reflecting all components of healthcare systems and programs, including the policy and cultural context in which they operate and both supply and demand. And unlike quality of care, a rights-based approach applies both to those served and those not served. It is characterized by participation, individual agency, and equity - with special attention to marginalized and vulnerable groups—and it stresses program accountability.

While a rights-based approach covers quality of care, the inverse is not true.” (Kumar, 2015: V)

\section{DEVELOPMENT PROCESS}

This review was undertaken by the Population Council as part of a project on quality of care funded by the David and Lucile Packard Foundation. A consultant expert in family planning programming, quality of care and rightsbased family planning undertook the review, with input from other experts.

\section{HOW TO USE IT / RESOURCES REQUIRED}

Use of this review does not require any special resources. 
WEB LINK

https://www.popcouncil.org/uploads/pdfs/2015RH_QOC-RightsBasedFP_wp1.pdf 


\section{VOLUNTARY FAMILY PLANNING PROGRAMS THAT RESPECT, PROTECT, AND FULFILL HUMAN RIGHTS: A CONCEPTUAL FRAMEWORK}

\begin{tabular}{|c|c|c|c|}
\hline DATE & PUBLISHER & LANGUAGES & FUNDING ORGANIZATION \\
\hline 2013 & Futures Group & English | French | Spanish | Hindi & $\begin{array}{c}\text { The Bill and Melinda Gates } \\
\text { Foundation }\end{array}$ \\
\hline
\end{tabular}

\section{TYPE OF RESOURCE}

A comprehensive programming framework that details a vision for what a voluntary, rights-based family planning program entails at the policy, service delivery, community and individual levels.

\section{PURPOSE}

This is a practical programming tool that provides a vision of an ideal, holistic FP program that respects, protects and fulfills human rights expressed in programmatic terms. It can be used for:

- Increasing awareness and understanding of what rights pertain in FP programs and how to make them concrete and actionable in FP programs

- Assessing, designing and improving programs

- Monitoring and evaluating programs; holding them accountable

- Creating strategic partnerships; identifying common ground between the public health and rights communities

This is the only framework that merges human rights and public health principles with elements of programming and quality of care frameworks, and that captures a view of a comprehensive, rights-based program in concise, graphic form.

\section{INTENDED AUDIENCES/USERS}

The Framework is intended for a wide range of stakeholders interested in promoting and providing voluntary, rights-based FP services, including policymakers, program managers, service providers, rights advocates, members of civil society organizations, donors, implementing organizations and researchers.

\section{SCOPE \& CONTENT}

Organized as a logic model, the Framework identifies key factors in the country context and details desired inputs or activities for four levels of the health system (policy, service delivery, community and individual) that lead to desired public health/ FP and human rights outputs and outcomes. It is anchored in the right to health (AAAQ), three categories of reproductive rights (to reproductive self-determination, to SRH services, information and supplies; to equality and nondiscrimination) and rights-related principles (PANEL).

\section{DEVELOPIMENT PROCESS}

A small Gates Foundation-funded team consisting of FP policy, program and human rights experts created a vision of what a human rights FP program that respects, protects and fulfills HR looks like, and developed a unifying framework that incorporates elements and principles from public health, family planning, holistic healthcare programming, quality of care and human rights. It was informed, and is supported, by systematic reviews of programmatic evidence and of tools related to voluntary, rights-based FP programs (the tools review is described below). Several drafts were shared at numerous convenings of public health, FP and human rights experts and civil society representatives. More than 200 global and country-level stakeholders from more than 25 countries reviewed various drafts. Their input was incorporated into the final document. 
HOW TO USE IT / RESOURCES REQUIRED

It can be used on its own to create understanding of what a comprehensive, rights-based FP program entails. To apply it in practice, it should be used in conjunction with the Users' Guide, described below.

\section{WEB LINK}

https://www.engenderhealth.org/files/pubs/family-planning/human-rights-based-familyplanning/Voluntary Family_Planning_Programs A Conceptual_Framework.pdf

https://www.engenderhealth.org/files/pubs/family-planning/human-rights-based-familyplanning/SUMMARY_BRIEF_Voluntary_Family_Planning_Programs.pdf

https://www.engenderhealth.org/files/pubs/family-planning/human-rights-based-familyplanning/FRENCH_Voluntary_Family_Planning_Programs_A_Conceptual_Framework.pdf

https://www.engenderhealth.org/files/pubs/family-planning/human-rights-based-familyplanning/SPANISH_Voluntary_Family_Planning_Programs_A_Conceptual_Framework.pdf

https://www.engenderhealth.org/files/pubs/family-planning/human-rights-based-familyplanning/HINDI_Voluntary_Family_Planning_Programs_A_Conceptual_Framework.pdf 


\section{VOLUNTARY FAMILY PLANNING PROGRAMS THAT RESPECT, PROTECT, AND FULFILL HUMAN RIGHTS: CONCEPTUAL FRAMEWORK USERS' GUIDE}

\begin{tabular}{|c|c|c|c|}
\hline DATE & PUBLISHER & LANGUAGES & $\begin{array}{c}\text { FUNDING } \\
\text { ORGANIZATION }\end{array}$ \\
\hline 2014 & Futures Group & English & $\begin{array}{l}\text { The Bill and Melinda } \\
\text { Gates Foundation }\end{array}$ \\
\hline
\end{tabular}

\section{TYPE OF RESOURCE}

This companion to the Voluntary, Rights-based Family Planning Conceptual Framework (described above) is a step-by-step "How to" guide that includes all support materials required for conducting an orientation to the framework and for leading stakeholders through a process to apply it in assessing, planning, monitoring and evaluating programs.

\section{PURPOSE}

This Guide enables users to apply the Voluntary, Rights-based FP Framework in practice.

\section{INTENDED AUDIENCES/USERS}

Like the Framework, the Users' Guide is intended for a wide range of stakeholders interested in promoting and providing voluntary, rights-based FP services, including policymakers, program managers, service providers, rights advocates, members of civil society organizations, donors, implementing organizations and researchers.

\section{SCOPE \& CONTENT}

The Guide is a complete resource package consisting of two modules, one for designing and conducting a workshop to introduce and orient stakeholders to the Framework, and one for a more in-depth workshop to apply the Framework in a seven-step process that generates the building blocks for a one-year action plan and a monitoring plan. It includes detailed facilitator guidance and participant workbooks, considerations for follow-up to the planning workshop and recommended next steps for moving quickly to action, plus background materials, supplementary references, tools and resources.

\section{DEVELOPMENT PROCESS}

The Guide was drafted by several members of the Framework development team. A field-test of the first draft was conducted in Uganda in 2014. It involved the $\mathrm{MOH}$, a USAID-funded RH project and a Gates Foundation-funded Implants project. Their feedback was incorporated into the final version.

\section{HOW TO USE IT / RESOURCES REQUIRED}

It can be used in orientations, needs assessments, advocacy, program design and improvement, monitoring and evaluating programs. All resources required are included in the Users' Guide (apart from local policy, strategy and program documents and data).

\section{WEB LINK}

https://www.engenderhealth.org/files/pubs/family-planning/human-rights-based-familyplanning/USERS GUIDE_Voluntary_Family_Planning_Programs.pdf 


\section{CHECKPOINTS FOR CHOICE:}

\section{AN ORIENTATION AND RESOURCE PACKAGE}

\begin{tabular}{|c|c|c|c|}
\hline DATE & PUBLISHER & LANGUAGES & FUNDING ORGANIZATION \\
\hline 2014 & $\begin{array}{c}\text { EngenderHealth/ } \\
\text { The RESPOND Project }\end{array}$ & English & $\begin{array}{l}\text { The William \& Flora Hewlett } \\
\text { Foundation and USAID }\end{array}$ \\
\hline
\end{tabular}

TYPE OF RESOURCE

Programming guidance

\section{PURPOSE}

This package provides all materials necessary to organize and conduct a workshop to strengthen the focus of FP programs on clients' rights and contraceptive choices, to strengthen a program's capacity to identify and address vulnerabilities related to full, free and informed choice, and to increase individuals' agency. Unlike other existing resources, it is written from the perspective of how the client experiences family planning programs.

\section{INTENDED AUDIENCES/USERS}

The package is intended for experienced facilitators to lead a workshop for diverse participants, including donors, policymakers, program planners and managers, service providers, staff of technical assistance agencies, and rights and community advocates.

\section{SCOPE \& CONTENT}

The package fills a gap by focusing on the client's perspective, preferences and experiences and on the many factors that affect an individual's ability to make full, free and informed choices about FP. It highlights the need to make FP programs client-centered rather than method-driven and to think critically about the extent to which contraceptive choice is protected in FP programs. It consists of a resource package for a one-day orientation to help FP stakeholders understand concepts related to full, free and informed choice and client-centered programming. Individual session plans, detailed guidance for facilitators, and all necessary support materials, plus a list of related reference materials and tools, are provided.

\section{DEVELOPMENT PROCESS}

It was developed by a team of EngenderHealth staff and consultants, some of whom were also involved in planning and conducting a consultation of experts in Bellagio in 2012 to explore the intersection of human rights and FP, and in developing the Voluntary, Rights-based FP Conceptual Framework. This package builds upon materials that were developed for the Bellagio consultation and responds to recommendations that came out of the deliberations. It was designed to complement the Voluntary, Rights-based FP Framework. It was pilot-tested with USAID staff in Washington, D.C. and in conjunction with the Voluntary, Rights-based FP Conceptual Framework Users' Guide in Uganda, both in 2014. Revisions based on the pilot- tests were incorporated into the final version.

\section{HOW TO USE IT / RESOURCES REQUIRED}

This is a complete package that can be used alone or in conjunction with other training, assessment or planning activities or tools to strengthen voluntarism, contraceptive choice, human rights and accountability in FP programs. Facilitators are encouraged to modify the workshop plan, selecting individual session to fit within time constraints and to focus on areas of greatest interest to stakeholders.

\section{WEB LINK}

https://www.engenderhealth.org/files/pubs/family-planning/Checkpoints-for-Choice-An-Orientation-andResource-Package.pdf 


\section{A HUMAN RIGHTS-BASED APPROACH TO PROGRAMMING: PRACTICAL IMPLEMENTATION MANUAL AND TRAINING MATERIALS}

\begin{tabular}{|c|c|c|c|}
\hline DATE & PUBLISHER & LANGUAGES & FUNDING ORGANIZATION \\
\hline 2010 & $\begin{array}{l}\text { UNFPA (with Harvard } \\
\text { School of Public Health) }\end{array}$ & English & UNFPA \\
\hline
\end{tabular}

TYPE OF RESOURCE

An in-depth conceptual overview of a human rights-based approach plus "How to" programming guidance and training materials.

\section{PURPOSE}

This manual provides step-by-step guidance on how to apply a culturally sensitive, gender-responsive, human rights-based approach to programming in each of UNFPA's three core areas of work: population and development, reproductive health, and gender. It also covers how to apply such an approach in the context of a humanitarian emergency. It aims to develop knowledge and provide tools necessary for building national capacity to implement a human rights-based approach in programming and policies at all levels from an ICPD perspective. The manual can be used as a stand-alone tool or in conjunction with the accompanying Training Materials (Power Point) as a basis for conducting a training in human rights-based programming.

\section{INTENDED AUDIENCES/USERS}

This manual was designed primarily for use by UNFPA Country Staff, but it can also be useful for UNFPA implementing partners and others working in the fields of population and development, sexual and reproductive health and reproductive rights, gender equality and women's empowerment.

\section{SCOPE \& CONTENT}

The content of this manual is based on the human rights-based approach described in the 2003 UN Statement of Common Understanding on a Human Rights-based Approach (HRBA) to Development Cooperation. It consists of three parts: the first covers core concepts of a human rights-based approach, the second provides guidance on application of a human rights-based approach, and the third consists of training materials which include a facilitator's manual. The document lists the human rights that are most relevant to UNFPA's work and UNFPAsupported actions that are inspired by these rights. It also translates rights principles into programmatic implications. It incorporates many examples based on UNFPA experience and includes worksheets and case studies. It offers in-depth conceptual content and practical programming guidance, explaining how each of the core human rights principles of a HRBA (especially the principles of participation and inclusion, equality and nondiscrimination, and accountability and Rule of Law) can be applied programmatically. It also introduces $3 \mathrm{AQ}$ (availability, accessibility, acceptability and quality), and provides guidance on what issues to consider with respect to operationalizing a HRBA at each stage of a typical programming cycle. 


\section{DEVELOPMENT PROCESS}

This manual was produced through a collaboration between the Program on International Health and Human Rights, Harvard School of Public Health and the Gender, Human Rights and Culture Branch of the UNFPA Technical Division, with the involvement of UNFPA staff and outside consultants. It draws from the Action 2 Common Learning Package, which stems from a global UN program designed to strengthen the capacity of country teams to support the efforts of Member States in reinforcing their national human rights promotion and protection systems. There was broad participation during the development process from UNFPA staff members, both at Headquarters and at Country Office level, as well as from other agencies. Four regional training centers played an important role in both the drafting and testing of this manual and training materials.

\section{HOW TO USE IT / RESOURCES REQUIRED}

It is designed to serve both as a 'how to' manual for conducting trainings as well as a reference on using an HRBA. It is self-contained; all necessary materials are included.

\section{WEB LINK}

http:/ / www.unfpa.org/resources/human-rights-based-approach-programming 


\section{THE RIGHT TO CONTRACEPTIVE INFORIMATION AND SERVICES FOR WOMEN AND ADOLESCENTS: BRIEFING PAPER}

\begin{tabular}{|c|c|c|c|}
\hline DATE & PUBLISHER & LANGUAGES & FUNDING ORGANIZATION \\
\hline 2010 & $\begin{array}{c}\text { Center for Reproductive Rights } \\
\text { and UNFPA, New York }\end{array}$ & English & UNFPA \\
\hline
\end{tabular}

\section{TYPE OF RESOURCE}

An overview of applicable human rights and program guidance for how to put a human rights-based approach into practice.

\section{PURPOSE}

This briefing paper lays out a conceptual foundation and provides practical guidance for how to integrate human rights into programs and policies related to contraceptive information and services.

\section{INTENDED AUDIENCES/USERS}

Activists, scholars, UN Agencies, NGOs, governments and other actors working in the area of sexual and reproductive health.

\section{SCOPE \& CONTENT}

The paper focuses specifically on the right to contraceptive information and services. It includes an overview of the problem of lack of access to contraceptive information and services for women and adolescents, lays out the human rights that underpin the right to access contraceptive information and services, and offers brief suggestions for how to put a human rights-based approach into practice. The Appendix cites specific regional and international treaty provisions related to contraceptive access which buttresses accountability.

\section{DEVELOPMENT PROCESS}

This is a joint product of the Center for Reproductive Rights and UNFPA. It was conceptualized by Center and UNFPA staff and was written by a team of lawyers under the guidance of UNFPA technical staff.

HOW TO USE IT / RESOURCES REQUIRED

No special skills, resources or steps required.

\section{WEB LINK}

http://www.unfpa.org/sites/default/files/resource-pdf/Contraception.pdf 
VOLUNTARY FAMILY PLANNING PROGRAMS THAT RESPECT, PROTECT, AND FULFILL HUMAN RIGHTS: A SYSTEMATIC REVIEW OF TOOLS

DATE

2013

\section{PUBLISHER}

Futures Group, Washington DC
LANGUAGES

English
FUNDING ORGANIZATION

The Bill and Melinda Gates

Foundation

TYPE OF RESOURCE

Compilation and synthesis of tools that support rights-based programming.

\section{PURPOSE}

This document offers synopses of tools that can be applied to support a rights-based approach in different stages of program assessment, planning and implementation.

\section{INTENDED AUDIENCES/USERS}

A broad range of FP program stakeholders, including donors, policymakers, managers, service providers and community members.

\section{SCOPE \& CONTENT}

This systematic review is a companion to the Voluntary, Rights-based FP Conceptual Framework. It compiles and synthesizes training and assessment tools, frameworks, methodologies, implementation guides, and job aids that support and promote the fulfillment of rights at the policy, service, community, and/or individual levels. It includes 150 documents that met defined selection criteria, and identifies where additional resources are required.

\section{DEVELOPMENT PROCESS}

These reviews were undertaken by the same team that developed the Voluntary, Rights-based, FP Conceptual Framework comprised of staff and consultants from the Futures Group and EngenderHealth, with input from a wide range of reviewers. The search strategy was guided by a series of questions related to what a successful voluntary, right-based FP program should include. The evidence search included principles approaches and intervention studies. The tools review used a long list of search terms to identify training tools, assessment tools, frameworks, methodologies, implementation guidance and job aids. Both documents are structured in alignment with the architecture of the framework, which recognizes four levels of the health system (policy, service delivery, community and individual).

\section{HOW TO USE IT / RESOURCES REQUIRED}

These are reference documents that don't require any particular skills or additional resources.

\section{WEB LINK}

https://www.engenderhealth.org/files/pubs/family-planning/human-rights-based-familyplanning/TOOLS Voluntary_Family_Planning_Programs_Systematic Review.pdf 


\section{REPRODUCTIVE RIGHTS ARE HUMAN RIGHTS: A HANDBOOK FOR NATIONAL HUMAN RIGHTS INSTITUTIONS}

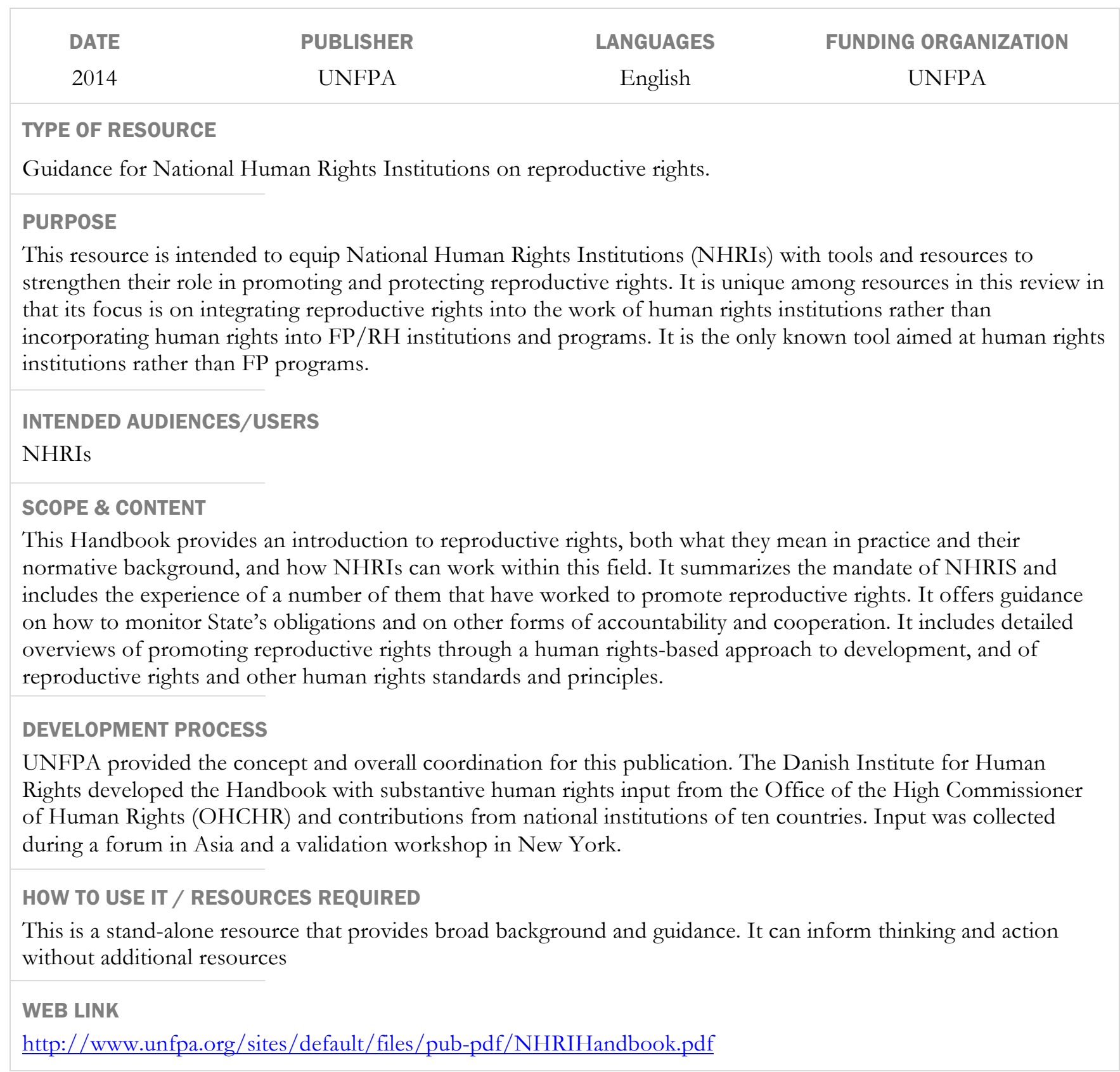




\section{References}

Center for Reproductive Rights. 2009. Reproductive Rights are Human Rights 2009. New York: Center for Reproductive Rights.

Center for Reproductive Rights and UNFPA. 2010. The Right to Contraceptive Information and Services for Women and Adolescents: Briefing Paper. New York: Center for Reproductive Rights.

Cottingham, J., Germain, A., and Hunt, P. 2012. Use of human rights to meet the unmet need for family planning. The Lancet 380(9837): 172-180.

Department for International Development (DFID). 2005. How to Reduce Maternal Deaths: Rights and Responsibilities. London: DFID, Policy Division.

Erdman, J. N., and Cook, R. J. 2008. Reproductive Rights. International Encyclopedia of Public Health. Editor-inChief: Kris. Oxford, Academic Press: 532-538.

FP2020. Rights and Empowerment Working Group. 2014. Family Planning 2020: Rights and Empowerment Principles for Family Planning. Washington, DC: FP2020.

Gruskin, S., Mills, E.J., and Tarantola, D. 2007. "History, principles, and practice of health and human rights." The Lancet 370(9585): 449-455.

Hardee, K., K. Newman, L. Bakamjian, J. Kumar, S. Harris, M. Rodriguez, and K. Willson. 2013. Voluntary Family Planning Programs that Respect, Protect, and Fulfill Human Rights: A Conceptual Framework. Washington, DC: Futures Group.

Holt, K, C Dehlendorf, and A Langer. 2017. "Defining Quality in Contraceptive Counseling to Improve Management of Individuals' Experiences and Enable Service Delivery Improvement.” Contraception. 96: 133-137.

International Planned Parenthood Federation (IPPF). 1996. IPPF Charter on Sexual and Reproductive Rights. London: IPPF.

Jain, A. 2017. "Quality of Care in the Context of Rights-based Family Planning." Policy Brief. New York: Population Council.

Kumar, J. 2015. "How Does Quality of Care Relate to a Rights-based Approach to Family Planning Programs?" New York: Population Council.

Kumar, J., L. Bakamjian, H. Connor, and S. Harris. 2013. Voluntary Family Planning Programs that Respect, Protect, and Fulfill Human Rights: A Systematic Review of Tools. Washington, DC: Futures Group and EngenderHealth.

Kumar, J., L. Bakamjian, S. Harris, M. Rodriguez, N. Yinger, C. Shannon and K. Hardee. 2014. Voluntary Family Planning Programs that Respect, Protect, and Fulfill Human Rights: Conceptual Framework Users' Guide. Washington, DC: Futures Group.

The RESPOND Project. 2014. Checkpoints for choice: An orientation and resource package. New York: EngenderHealth/The RESPOND Project. 
Office of the High Commissioner for Human Rights (OHCHR). 2006. Frequently Asked Questions on a Human Rights-based Approach to Development Cooperation. New York and Geneva: OHCHR.

OHCHR. 2016. General comment No. 22 (2016) on the right to sexual and reproductive bealth (article 12 of the International Covenant on Economic, Social and Cultural Rights). New York and Geneva: Office of the High Commissioner for Human Rights (OHCHR).

United Nations Population Fund (UNFPA). 2010. A Human Rights-based Approach to Programming/Practical Implementation Manual and Training Materials. New York: UNFPA and Boston: Harvard School of Public Health.

UNFPA. 2014. Reproductive Rights are Human Rights. A Handbook. for National Human Rights Institutions. New York: UNFPA.

UNFPA, Danish Institute for Human Rights and UNOHCRH. 2014. Reproductive Rights are Human Rights. $A$ Handbook for National Human Rights Institutions. New York: UNFPA.

UNFPA and Harvard School of Public Health. 2010. A Human Rights-based Approach to Programming: Practical Implementation Manual and Training Materials. New York: UNFPA.

WHO and UNFPA. 2015. Ensuring Human Rights Within Contraceptive Service Delivery: Implementation Guide. Geneva: WHO.

WHO. 2014. Ensuring Human Rights in the Provision of Contraceptive Information and Services. Geneva: WHO.

WHO. 2017. Monitoring Human Rights in Contraceptive Services and Programmes. Geneva: WHO.

WHO. 2017. Quality of Care in Contraceptive Information and Services, Based on Human Rights Standards: A Checklist for Health Care Providers. Geneva: WHO. . 


\section{The Evidence Project}

Population Council

4301 Connecticut Avenue, NW, Suite 280

Washington, DC 20008 USA

tel +12022379400

evidenceproject.popcouncil.org 